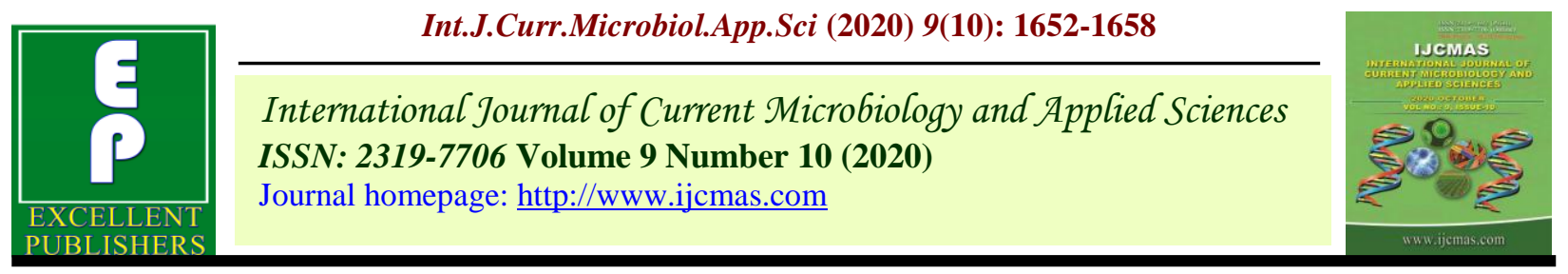

\title{
Survey, Surveillance \& Cultural Characteristics of Dry Root Rot of Chickpea caused by Rhizoctonia bataticolain Derapur Tahsil, Kanpur
}

\author{
Anurag Shukla ${ }^{1 *}$, Ved Ratan ${ }^{1}$, R K Mishra ${ }^{2}$, Krishna Kumar ${ }^{2}$, U. K. Tripathi ${ }^{1}$, D. R. \\ Singh $^{3}$, R. K. Pathak ${ }^{4}$, Javed Bahar ${ }^{1}$, Anjani Kumar Singh ${ }^{5}$ and Kripa Shankar ${ }^{3}$ \\ ${ }^{1}$ Department of Plant Pathology, ${ }^{2}$ Division of Crop Protection, IIPR, Kanpur, India \\ ${ }^{3}$ Department of Entomology, ${ }^{4}$ Department of Soil Science \& Agri. Chemistry, ${ }^{5}$ Department of \\ Agri. Economics \& Statistics, C.S.A.U.A \& T, Kanpur-2, Uttar Pradesh, India \\ *Corresponding author
}

\author{
A B S T R A C T
}

\begin{tabular}{|c|}
\hline Keywords \\
\hline $\begin{array}{l}\text { Dry root rot, } \\
\text { Rhizoctonia } \\
\text { bataticola, } \\
\text { Macrophominaphas } \\
\text { eolina, Colony } \\
\text { Diameter, } \\
\text { Pigmentation, } \\
\text { Aerial hyphae }\end{array}$ \\
\hline Article Info \\
\hline $\begin{array}{l}\text { Accepted: } \\
12 \text { September } 2020 \\
\text { Available Online: } \\
10 \text { October } 2020\end{array}$ \\
\hline
\end{tabular}

Dry root rot caused by Rhizoctonia bataticola (Taub.) Butler [Pycnidial stage: Macrophomina phaseolina (Tassi) Goid] is a soil borne fungal pathogen. Keeping in view the importance of the disease due to change in climatic conditions, studies were conducted on distribution of the disease, cultural, morphological, pathological and molecular diversity. The experiment was conducted at Department of Plant Pathology CSA, Kanpur. In the present studies, twelve isolates of $R$. bataticola were isolated form disease sample of dry root rot of chickpea collected from different farmer's fields from twelve villages in Derapurtahsil in Kanpur, Uttar Pradesh, India. The pathogen was isolated and purified in PDA media by using standard isolation procedure and its pathogenicity was proven in pot culture. Further, on the basis of cultural characteristics and morphological characteristics of the pathogen, the fungal pathogen was identified as $R$. bataticola. In cultural characteristics six characters like colony colour, colony diameter, pigmentation, margin type, growth pattern and aerial hyphae were recorded. Maximum radial growth i.e. $90 \mathrm{~mm}$ was given by isolate Rb-07 of Sabalpur village followed by Rb-02 and Rb-12. Least radial growth of $45 \mathrm{~mm}$ was given by $\mathrm{Rb}-03$ isolate of Nandpur village. Pigmentation was also observed in four isolates. Aerial hyphae were produced by six isolates.

\section{Introduction}

Uttar Pradesh is a northern State and located between $26.85^{\circ} \mathrm{N} 80.91^{\circ} \mathrm{E}$. The State of Uttar Pradesh falls under three agro-climatic zones viz. (a) Agro Climatic Zone-IV: Middle Gangetic Plains region,(b) Agro Climatic Zone-V: Upper Gangetic Plains region and (c) Agro Climatic Zone-VIII: Central Plateau and Hills region. The Agro-climatic zone- V is among the larger and very thickly populated agro-climatic zones. The zone is characterized by semi-arid and sub-humid conditions. The mean Annual rainfall varies between 700 and $1,000 \mathrm{~mm}$. There are three sub-zones under this agro-climatic zone viz. (i) Central Plains, (ii) North-Western Plains and (iii) South-Western Plains. South- 
Western Plains has high proportion of arable and irrigated cropped area. The climate is semi-arid and the soil type is alluvium calcareous clay. The region receives about $721 \mathrm{~mm}$ of rainfall. More than $74 \%$ of the net sown area is irrigated and over $69 \%$ land is cultivated. This is largely on account of cultivation of low value crops principally wheat, bajra and chickpea. The region covers the districts of Badaun, Aligarh, Mathura, Agra, Etah, Farrukhabad, Kannauj, Mainpuri, Firozabad, Etawah, Kanpur Dehat, Derapur and Kanpurnagar.

Uttar Pradesh state has a total area of 577 thousand ha, production of 475.4 thousand tones and yield $824 \mathrm{~kg} / \mathrm{ha}$ under chickpea cultivation (Rajbhar et al., 2018). Fifty different pathogens have so far been reported on chickpea (Nene et al., 1989) including diseases caused by fungal, bacterial, nematodes mycoplasma and viral pathogen. Dry root rot of chickpea is caused by Rhizoctonia bataticola is a soil and seedborne necrotrophic fungal pathogen (Sharma and Pande 2013). It is one of the important diseases which mostly occurs under drought conditions and prevail at flowering and podding stage of the crop. It infects more than 284 plant species including monocot and dicot plant hosts (Farr et. al., 1995). The disease is favoured by high soil temperature $\left(>30^{\circ} \mathrm{C}\right)$ and low soil moisture condition. The first report of occurrence of dry root rot in chickpea along with wilt was made by Padwick (Padwick, 1948).

Significant reduction of $25-70$ per cent in chickpea production due to this disease in India has been reported (Ahmed and Ahmed 1969), (Pande and Sharma 2010). Environmental conditions like temperature, soil moisture and $\mathrm{pH}$ play an important role in the viability and growth of Rhizoctonia bataticola (Khare et al., 1970). This investigation was carried out to find out the severity of dry root rot caused by Rhizoctonia bataticola in chickpea in Kanpur region of the Uttar Pradesh state. Survey and surveillance of dry root rot of chickpea was done on farmer's field. Collection, isolation, purification and pathogenicity of the Rhizoctonia bataticola were studied.

\section{Materials and Methods}

\section{Survey and Surveillance}

A survey of chickpea fields was conducted in the twelve villages in DerapurTehsil viz., Paraukh, Malatipur, Nandpur, DevkiPurwa, Kapasi, Nunariya, Sabalpur, Khajurra, MawaiMukta, Nanthu, Salempur and Akaaruin Kanpur Dehat during the month of February and March to record the incidence of dry root rot of chickpea On an average, 03 farmer's fields of chickpea in each village were visited. Chickpea plants showing typical dry root rot symptoms were uprooted collected in separate paper bags and specifications like village name, latitude, longitude and crop stage were recorded and brought to the laboratory for further investigations (Table 1).

\section{Isolation and purification}

Chickpea roots showing dry root rot symptoms were washed under running tap water and blot dried. Infected roots were cut into pieces of $4-5 \mathrm{~mm}$ size and were surface sterilized by 1 per cent sodium hypochlorite $(\mathrm{NaOCl})$ solution. After thorough washing in sterile distilled water, the pieces were then transferred by using forceps on to sterilized PDA media and incubated at $28 \pm 2{ }^{0} \mathrm{C}$ in BOD incubator (Anurag \& Ved, 2019). The fungal colonies emanating from bits were examined on 4 days of incubation growing mycelium was marked on the underside and viewed through a light microscope. 


\section{Pathogenicity test}

Pathogenicity of the organism was confirmed by sick pot technique in earthern pots under greenhouse condition by using susceptible cultivar of chickpea variety BG-212 (Prameela Devi and Singh, 1998).

Inoculum was prepared from the 10 days old culture of Rhizoctonia bataticola grown on $100 \mathrm{gm}$ of sand maize meal media. Sand maize meal media was prepared by using sand and maize meal in 2:1 ratio, for the preparation of this media maize grains were broken into 3 to 4 pieces by using grinder just like porridge, this was soaked in sterile distil water for 12 hours. After 12 hours excess water from maize was removed and sterile sand was added and properly mixed. Put $100 \mathrm{gm}$ sand maize meal media in $250 \mathrm{ml}$ flask and autoclave all the 100 conical flask having media at $15 \mathrm{lbs}$. for 20 minutes. After cooling, the flasks were then inoculated with five $\mathrm{mm}$ disc of seven days old culture of Rhizoctonia bataticola and incubated at $28 \pm$ $2^{0} \mathrm{C}$. After 15 days of incubation, the inoculum was taken out from the flask and a fungus-soil mixture by hand mixing the pathogen @ $50 \mathrm{~g} / \mathrm{kg}$ autoclaved soil was prepared. Fill pots with the inoculated soil. Approximately $2 \mathrm{~kg}$ of sterile soil and $500 \mathrm{gm}$ of sterile FYM will be required to fill each pot (Mamta Sharma et al., 2015). Water the pots and wait for 4 days before proceeding to the next step. 15 chickpea seeds of variety BG212 were sown on each pot with two replication of each isolate with two control pots.

All these pots were then watered lightly and kept in a glass-house for further recording of observations on per cent seed germination, seedling mortality, etc. The observations on dry root rot incidence were recorded after 15 days of germination to flowering stage. Reisolation of the pathogen was made from roots of artificially inoculated and diseased plants showing the typical symptoms of dry root rot. The fungus growth obtained was transferred on potato dextrose agar slants for comparison with the original culture of Rhizoctonia bataticola. The symptoms of dry root rot were observed and recorded right from the initiation of the disease till the complete death of plants both in pot culture as well as under field condition. The culture of the pathogen obtained was identified on the basis of morphological and cultural characteristics. (Mayek et al., 2002).

\section{Cultural characteristics}

In cultural characteristics six characters like colony colour, colony diameter, pigmentation, margin type, growth pattern and aerial hyphae were recorded. Colony characters and sclerotia production ability of the isolates of Rhizoctonia bataticola were studied by growing it on potato dextrose agar media (PDA). The PDA media was prepared by following standard laboratory procedure given by Twite (1969), ansterilized by autoclaving at $15 \mathrm{lbs}$. for 20 minutes. After sterilization media was poured into sterile plastic petri plates and allowed to cool down and solidify. Then, the plates were inoculated with 2-5 mm disc of seven days old culture of Rhizoctonia bataticola and incubated at $28 \pm$ $2^{0} \mathrm{C}$ in BOD incubator.

\section{Results and Discussion}

\section{Pathogenicity}

Pathogenicity of the fungus was carried out in pot culture by using chickpea variety BG-212 which exhibited symptoms of dry root rot after 25 days of inoculation. The initial symptoms include yellowing, drooping of the petioles and leaflets only on the tips (Gupta et. al., 2012). Leaves and stems of the affected plants are straw colored; in some 
cases, lower leaves turn brown, tap root turns black, shows signs of rotting, and is devoid of lateral and finer roots. A grayish mycelium can sometimes be seen on the tap root. The dead roots are quite brittle and show shredding of bark and lateral root. Minute sclerotia can be seen on the exposed wood of the root and inner side of the bark or whenever split open at the collar region vertically (Jayalakshmi et al., 2008). Symptoms of dry root rot produced by the artificially inoculated and diseased plants were identical and confirmed with those symptoms observed on naturally infected chickpea plants in the field.

Table.1 Survey dry root rot infected fields of chickpea in Derapur Tahsil

\begin{tabular}{|r|l|l|l|l|l|}
\hline S.No & \multicolumn{1}{|c|}{ Place } & \multicolumn{1}{|c|}{ Village Name } & \multicolumn{1}{c|}{ Lattitude } & \multicolumn{1}{c|}{ Longitude } & \multicolumn{1}{c|}{ Crop Stage } \\
\hline $\mathbf{0 1}$ & Derapur & Paraukh & $26^{\circ} 27^{\prime} 18^{\prime \prime} \mathrm{N}$ & $79^{\circ} 44^{\prime} 06^{\prime \prime} \mathrm{E}$ & Flowering \\
\hline $\mathbf{0 2}$ & Derapur & Malatipur & $26^{\circ} 37^{\prime} 12^{\prime \prime} \mathrm{N}$ & $79^{\circ} 42^{\prime} 03^{\prime \prime} \mathrm{E}$ & Flowering \\
\hline $\mathbf{0 3}$ & Derapur & Nandpur & $26^{\circ} 22^{\prime} 02^{\prime \prime} \mathrm{N}$ & $79^{\circ} 47^{\prime} 47^{\prime \prime} \mathrm{E}$ & Flowering \\
\hline $\mathbf{0 4}$ & Derapur & DevkiPurwa & $26^{\circ} 32^{\prime} 45^{\prime \prime} \mathrm{N}$ & $79^{\circ} 53^{\prime} 03^{\prime \prime} \mathrm{E}$ & Flowering \\
\hline $\mathbf{0 5}$ & Derapur & Kapasi & $26^{\circ} 29^{\prime} 18^{\prime \prime} \mathrm{N}$ & $79^{\circ} 45^{\prime} 17^{\prime \prime} \mathrm{E}$ & Podding \\
\hline $\mathbf{0 6}$ & Derapur & Nunariya & $26^{\circ} 33^{\prime} 29^{\prime \prime} \mathrm{N}$ & $79^{\circ} 48^{\prime} 12^{\prime \prime} \mathrm{E}$ & Podding \\
\hline $\mathbf{0 7}$ & Derapur & Sabalpur & $27^{\circ} 1^{\prime} 38^{\prime \prime} \mathrm{N}$ & $79^{\circ} 25^{\prime} 06^{\prime \prime} \mathrm{E}$ & Flowering \\
\hline $\mathbf{0 8}$ & Derapur & Khajurra & $26^{\circ} 27^{\prime} 29^{\prime \prime} \mathrm{N}$ & $79^{\circ} 48^{\prime} 22^{\prime \prime} \mathrm{E}$ & Podding \\
\hline $\mathbf{0 9}$ & Derapur & MawaiMukta & $26^{\circ} 21^{\prime} 22^{\prime \prime} \mathrm{N}$ & $79^{\circ} 48^{\prime} 21^{\prime \prime} \mathrm{E}$ & Podding \\
\hline $\mathbf{1 0}$ & Derapur & Nanthu & $26^{\circ} 22^{\prime} 43^{\prime \prime} \mathrm{N}$ & $79^{\circ} 46^{\prime} 50^{\prime \prime} \mathrm{E}$ & Flowering \\
\hline $\mathbf{1 1}$ & Derapur & Salempur & $26^{\circ} 24^{\prime} 40^{\prime \prime} \mathrm{N}$ & $79^{\circ} 46^{\prime} 58^{\prime \prime} \mathrm{E}$ & Podding \\
\hline $\mathbf{1 2}$ & Derapur & Akaaru & $26^{\circ} 30^{\prime} 55^{\prime \prime} \mathrm{N}$ & $79^{\circ} 47^{\prime} 10^{\prime \prime} \mathrm{E}$ & Flowering \\
\hline
\end{tabular}

Table.2 Cultural characteristics of different isolates of $R b$ from different locations of Derapur Tahsil

\begin{tabular}{|c|c|c|c|c|c|c|c|c|c|}
\hline S.No & Place & Village & $\begin{array}{c}\text { Isolate } \\
\text { No. }\end{array}$ & $\begin{array}{l}\text { Colony } \\
\text { Colour }\end{array}$ & $\begin{array}{c}\text { Colony } \\
\text { Diameter }\end{array}$ & Pigmentation & $\begin{array}{c}\text { Margin } \\
\text { Type }\end{array}$ & $\begin{array}{l}\text { Growth } \\
\text { Pattern }\end{array}$ & $\begin{array}{c}\text { Aerial } \\
\text { Hyphae }\end{array}$ \\
\hline 01 & Derapur & Paraukh & Rb-01 & Black & $55 \mathrm{~mm}$ & No & Regular & Flat & Present \\
\hline 02 & Derapur & Malatipur & Rb-02 & Black & $85 \mathrm{~mm}$ & No & Regular & Flat & No \\
\hline 03 & Derapur & Nandpur & Rb-03 & Gray & $45 \mathrm{~mm}$ & Yes & Irregular & Fluffy & No \\
\hline 04 & Derapur & DevkiPurwa & Rb-04 & Black & $80 \mathrm{~mm}$ & No & Regular & Flat & Present \\
\hline 05 & Derapur & Kapasi & Rb-05 & Black & $57 \mathrm{~mm}$ & No & Irregular & Flat & No \\
\hline 06 & Derapur & Nunariya & Rb-06 & Gray & $50 \mathrm{~mm}$ & Yes & Regular & Fluffy & Present \\
\hline 07 & Derapur & Sabalpur & Rb-07 & Black & $90 \mathrm{~mm}$ & No & Regular & Flat & No \\
\hline 08 & Derapur & Khajurra & Rb-08 & Gray & $70 \mathrm{~mm}$ & No & Regular & Flat & No \\
\hline 09 & Derapur & MawaiMukta & Rb-09 & Black & $55 \mathrm{~mm}$ & No & Irregular & Fluffy & Present \\
\hline 10 & Derapur & Nanthu & Rb-10 & Black & $50 \mathrm{~mm}$ & Yes & Regular & Flat & Present \\
\hline 11 & Derapur & Salempur & Rb-11 & Gray & $75 \mathrm{~mm}$ & No & Regular & Flat & Present \\
\hline 12 & Derapur & Akaaru & Rb-12 & Black & $85 \mathrm{~mm}$ & Yes & Irregular & Fluffy & No \\
\hline
\end{tabular}


Fig.1 Radial growth in mm of different isolates of $R b$ from different locations of DerapurTahsil

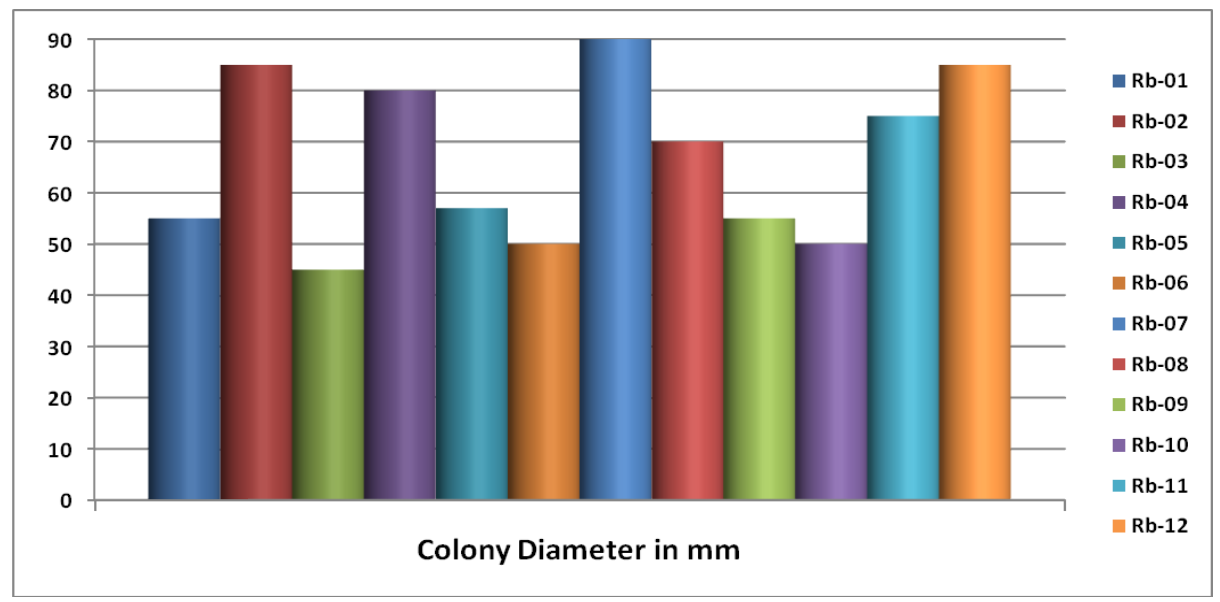

\section{Identification of fungal pathogen}

The pathogenic culture isolated from the diseased plants was identified on the basis of the morphological characters like presence of sclerotia and right angled hyphae and was confirmed by using, "Leica DM 2000 Compound Microscope" from Dept. of plant Pathology, C.S.A University of Agriculture \& Technology, Kanpur-208002.

\section{Cultural Characteristics}

The results with respect to the colony characteristics of Rhizoctonia bataticola on various culture media are presented in Table 2. From that result, it was revealed that there was a significant difference in cultural characteristics among different isolates from different villages of Derapur tehsil. Eight isolates among twelve were producing black colour colony and remaining four were showing gray colour. In radial growth there were three types of isolates i.e. fast growing, medium and slow growing (Figure 1). In fast growing isolates, colony diameter must be more than $80 \mathrm{~mm}$, three isolates viz., Rb-02, $\mathrm{Rb}-07$ and Rb-12 showed diameter of $85 \mathrm{~mm}$, $90 \mathrm{~mm}$ and $85 \mathrm{~mm}$ respectively, belongs to this category followed by medium growing (between 60 to $80 \mathrm{~mm}$ ) three isolates like Rb-
04, Rb-08 and Rb-11 showed medium colony diameter. In third category the colony diameter must be less than $60 \mathrm{~mm}$; six isolates like $\mathrm{Rb}-01, \mathrm{Rb}-03, \mathrm{Rb}-05, \mathrm{Rb}-06, \mathrm{Rb}-$ 09 and $\mathrm{Rb}-10$ were showing slow colony growth. Pigmentation was also observed in four isolates like Rb-03, Rb-06, Rb-10 and $\mathrm{Rb}-12$. Rhizoctonia bataticola showed two types of margins i.e. regular and irregular. Regular margin was showed by eight isolates like Rb-01, Rb-02, Rb-04, Rb-06, Rb-07, Rb$08, \mathrm{Rb}-10$ and $\mathrm{Rb}-11$ and four isolates were showing irregular margin. There were two type of growth pattern i.e. flat and fluffy, in case of $\mathrm{Rb}$. Four isolates Rb-03, Rb-06, Rb09 and $\mathrm{Rb}-12$ were showing fluffy pattern while remaining eight isolates were showing flat pattern. Aerial hyphae were also produced by six isolates like Rb-01, Rb-04, Rb-06, Rb09, Rb-10 and Rb-11.

The symptoms produced were exactly identical to those described earlier by Sharma et al., (2015), Narsimhan (1929)and Mehrotra and Aneja (1990). Pure culture of Rhizoctonia bataticola was again when re-inoculated on chickpea cultivar BG-212 in pot culture and the symptoms shows that affected plants are straw colored and the tap root turns black, shows signs of rotting, and is devoid of lateral and finer roots. The dead roots are quite 
brittle and show shredding of bark and lateral root and minute black sclerotia can be also be seen on the tap root. Such seedling becomes straw coloured, dry and collapsed within few days. The symptoms of dry root rot of chickpea observed were similar to those recorded earlier by Sharma et al., (2015), and Mehrotra and Aneja (1990). The cultural studies results obtained are in agreement with the findings of (Dhingra and Sinclair (1973a, 1973b); Arca et al., (1989)and Shekhar et al., (2006a). who also reported about the colony colour, colony diameter, pigmentation, margin type, growth pattern and aerial hyphae produced by Rhizoctonia bataticola in Potato dextrose agar media.

\section{Acknowledgment}

This paper and the research behind it would not have been possible without the exceptional support of my supervisor Dr. Ved Ratan, my co-advisor Dr. Krishna Kumar and our dean Dr. D R Singh. We are also thankful to Chandra Shekhar Azad University of Agriculture \& Technology, Kanpur, Uttar Pradesh, India as well as Indian Institute of Pulses Research, Kanpur, Uttar Pradesh, India for providing us all the facilities and infrastructure.

\section{Compliance with Ethical Standards}

The authors declare that they have no conflict of interest.

This article does not contain any studies with human participants or animals performed by any of the authors.

\section{References}

Ahmed, N., and Q.A. Ahmed.(1969). Physiologic specialization in Macrophominaphaseoli (Maubl.)Ashby, causing stem rot of Jute, Corchorus species. Mycyopath. Mycol. Appl. 39: 129-138.

Anurag Shukla and Ved Ratan. (2019). Management of Early Blight of Potato by Using Different Bioagents as tuber dressing and its effect on germination and growth..Int.J.Curr.Microbiol.App.Sci. 8(6): $\quad$ 1965-1970, DOI: http://doi.org/10.20546/ijcmas.2019.806 .233

Arca, G. and Yildzin, 1989.Investigation on the physiological variation of Macrophomina phaseolinain Aegean region. J. Turkish Phytopathol., 18 (12): 39-45. Astrovirus-associated epidemic gastroenteritis in Japan.Journal Med. Virol. 1982; 9 (1) : 11-70.

Dhingra, C. D. and Sinclair, J. B., 1973a.A location of Macrophomina phaseolina on soybean plants related to cultural characteristics and virulence. Phytopathol., 63: 934-936.

Dhingra, C. D. and Sinclair, J. B., 1973b., Variation among the isolates of Macrophomina phaseolina (Rhizoctonia bataticola) from different regions. Phytopathol., 76: 200-204.

Farr DF, Bills GF, Chamuris GP, Rossman AY (1995). Fungi on Plants and Plant Products in the United States, 2nd ed. St Paul, MN: APS Press.

Gupta Om, RathiManisha and Mishra Madhuri. 2012. Screening for resistance against Rhizoctonia bataticola causing dry root-rot in chickpea. J. Food Legumes 25:139-141.

Jayalakshmi SK, Usharani S, BenagiVI and Mannur DM. 2008.Sources of resistance to dry root rot of chickpea caused by Rhizoctonia bataticola. Agric. Science Digest 28:147-148.

Khare, M. N., Jain, N. K. and Sharma, H. C., (1970). Variation among Rhizoctonia bataticola isolates from urdbean plant parts and soil. Phytopathol., 60: 1298 
Mamta Sharma, RajuGhosh\& Suresh Pande (2015) Dry root rot (Rhizoctonia bataticola (Taub.) Butler): an emerging disease of chickpea - where do we stand?, Archives of Phytopathology and Plant Protection, 48:13-16, 797-812, DOI: 10.1080/03235408.2016.1140564

Mayek-Perez N, Garcia-Espinosa R, LopezCastaneda C, Acosta-Gallegos JA, Simpson, J. (2002). Water relations, histopathology, and growth of common bean (Phaseolus vulgaris L.) during pathogenesis of Macrophomina phaseolina under drought stress. Physiol Plant Pathol, 60, 185-195.

Mehrotra, R. S. and K. R. Aneja (1990).“An introduction to mycology". New age international (P) Ltd. Publisher, New Delhi 610-617.

Narasimhan, R. (1929).A preliminary note on Fusarium parasite on Bengal gram $(C$. arietinum L.).Madras Agri. Dept. Year Book. P: 5.

Nene YL, Shelia VK, Sharma SB (1989).A world list of chickpea and pigeonpea diseases. Legume Pathology Progress Report - 7, ICRISAT Publication.

Padwick, G.W. 1948.Plant protection and food crops of India, plant pest and disease at rice, wheat, sorghum and gram. Imperial J. Exp. Agri. 16: 55-64.

Pande, S. and Sharma, M. (2010). Climate Change: Potential Impact on Chickpea and Pigeonpea Diseases in the Rainfed Semi-Arid Tropics (SAT). In: 5th International Food Legumes Research
Conference (IFLRC V) \& 7th European Conference on Grain Legumes (AEP VII) April 26-30, 2010. Antalya, Turkey.

Prameela Devi and Singh, R. H. (1998). Studies on virulence of Macrophomina phaseolina isolates from blackgram and greengram. J. Mycol. Pl. Pathol. 22(2): 196-198.

Rajbhar AK, Singh HC, Jha KK, Kumar Mohit and MauryaKuldeep (2018)Adoption of chickpea production technology amongfarmers in central plain zone of Uttar Pradesh.Journal of Pharmacognosy and Phytochemistry 2018; 7(4): 2250-2254

Sharma M and Pande S. (2013).Unravelling effects of temperature and soil moisture stress response on development of dry root rot [Rhizoctonia bataticola (Taub.)] butler in chickpea. American Journal of Plant Sci. 4:584-589.

Sharma M, Ghosh R., Pande S. Dry root rot (Rhizoctonia bataticola (Taub.) Butler) 2015: an emerging disease of chickpeawhere do we stand? Arch Phytopathol Plant Prot. 2015; 48(13-16):797-812.

Shekhar, M., Sharma, R. C., Singh, L. and Dutta, R., 2006a, Morphological and pathogenic variability of Macrophomina phaseolina (Tassi) Goid.incitant of charcoal rot of maize in India. Indian Phytopathol., 59(4) : 453-459.

Twite J (1969). Plant Pathological Methods. Fungi and Bacteria. Burgess Publishing Co., pp. 12-80.

\section{How to cite this article:}

Anurag Shukla, Ved Ratan, R. K. Mishra, Krishna Kumar, U. K. Tripathi, D. R. Singh, R. K. Pathak, Javed Bahar, Anjani Kumar Singh and Kripa Shankar. 2020. Survey, Surveillance \& Cultural Characteristics of Dry Root Rot of Chickpea caused by Rhizoctonia bataticolain Derapur Tahsil, Kanpur. Int.J.Curr.Microbiol.App.Sci. 9(10): 1652-1658.

doi: https://doi.org/10.20546/ijcmas.2020.910.199 